\title{
New Model Configuration for Post Combustion Carbon Capture
}

\author{
Udara S. P. R. Arachchige, Dinesh Kawan, and Morten C. Melaaen
}

\begin{abstract}
This paper discusses about possible configurations to improve the process with reduction of re-boiler energy demand. The simulations are performed in the Aspen Plus process simulation tool to check the required re-boiler duty. In the new model configuration, the rich solvent to the stripper is split using splitter block and supplied to the stripper section. The re-boiler duty for $85 \%, 90 \%$ and $95 \%$ removal efficiency cases are calculated for new model configuration and it is $\mathbf{3 2 5 5}$, 3360 and $3614 \mathrm{~kJ} / \mathrm{kg} \mathrm{CO}_{2}$ respectively. This is around $10 \%$ reduction of re-boiler duty compare to the conventional process.
\end{abstract}

Index Terms-Carbon capture, model configuration, post combustion, re-boiler duty.

\section{INTRODUCTION}

Global climate change is one of the most prominent environmental issues in present time. There are several activities mainly contributing for accumulation of green house gases, such as burning of fossil fuels, industrial processes and various human activities. Therefore, reduction of green house gas emissions such as mainly carbon dioxide $\left(\mathrm{CO}_{2}\right)$ is an important issue. There are several actions that can be activated to reduce the emissions. Increase of renewable energy sources is one of the possible discussions all around the world. However, time that will take renewable energy to penetrate the energy market implies significant continued use of fossil fuels. Carbon dioxide capture and storage (CCS) are considered as one of the main viable option for reduction of green house gas emissions from power plants [1].

Carbon capture technologies are not exactly new method and it started few decades ago. However, the CCS technologies use in the power plant emission reduction is not currently used as a reduction method due to high energy requirement in solvent regeneration process. The post combustion chemical absorption process is the most prominent technique to use for carbon capture. The acid gas mainly $\mathrm{CO}_{2}$ can be chemically captured with amine solvents. Once $\mathrm{CO}_{2}$ has been captured with amine solvent, it can be regenerated to collect purified $\mathrm{CO}_{2}$. However, with the current scenario, post combustion chemical absorption process imposes an energy penalty of about $30 \%$ to $60 \%$ for coal fired power plants [2]. Therefore, reduction of energy requirement in carbon capture process is important to implement in the real industries. This paper discuss about

Manuscript received November 9, 2012; revised January 23, 2013.

The authors are with the Telemark University College, Porsgrunn, Norway (e-mail: udara.s.p.arachchige@hit.no; kawandinesh@gmail.com; Morten.C.Melaaen@hit.no). possible model configurations to improve the process with reduction of re-boiler energy demand.

\section{PROCESS DESCRIPTION}

The basic post combustion process used in the carbon capture process is modified to get lower re-boiler duty. The flue gas data from $500 \mathrm{MW}$ coal fired power plant is considered for the simulation studies [3]. The simulations are performed in the Aspen Plus process simulation tool to check the required re-boiler duty. The electrolyte NRTL property method is used for simulation studies [4]. The packing materials used in the process development are selected according to the literatures [5]. The optimized solvent properties are used from previous studies [6]. Monoethanolamine (MEA) is selected as the solvent for absorption process.

The process configuration has slightly been changed to optimize the process. The parameter values use to develop the process model is similar to basic model [6]. Fig. 1 presents the base case model which is normally used for all the simulation studies. In new model configuration, rich solvent entering to the stripper is split using splitter block and supplied to the stripper section. The splitter ratio, stage number in stripper and split stream temperatures are varied to check the optimum values to get minimum re-boiler duty. The flow diagram of the new process model configuration is given in Fig. 2.

\section{A. Flue Gas and Solvent Stream Data}

The flue gas and solvent stream data use in the simulations are given in Table I and Table II. The optimized data is selected from the previous studies for both conventional and new configuration.

\begin{tabular}{lc}
\multicolumn{2}{c}{ TABLE I. FLUE GAS STREAM DATA [3] } \\
\hline Coal fired flue gas \\
\hline Flow rate $[\mathrm{kg} / \mathrm{s}]$ & 673.4 \\
\hline Temperature $[\mathrm{K}]$ & 313 \\
\hline Pressure $[\mathrm{bar}]$ & 1.1 \\
\hline Major Composition & Mol\% \\
\hline $\mathrm{H}_{2} \mathrm{O}$ & 8.18 \\
\hline $\mathrm{N}_{2}$ & 72.86 \\
\hline $\mathrm{CO}_{2}$ & 13.58 \\
\hline $\mathrm{O}_{2}$ & 3.54 \\
\hline $\mathrm{H}_{2} \mathrm{~S}$ & 0.05 \\
\hline
\end{tabular}




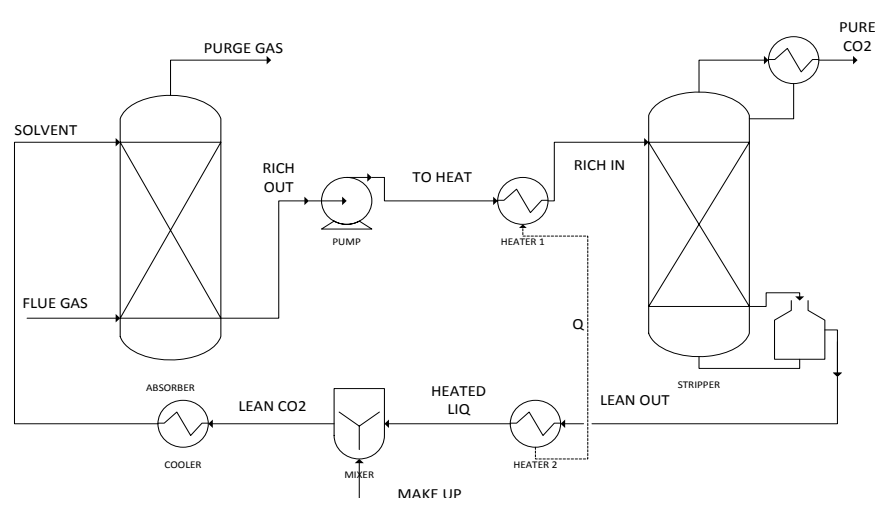

TABLE II. SOLVENT STREAM DATA [6]

\begin{tabular}{lccc}
\hline & \multicolumn{3}{c}{$\begin{array}{c}\text { Removal } \\
\text { Efficiency }\end{array}$} \\
\hline Specification & $85 \%$ & $90 \%$ & $95 \%$ \\
\hline MEA concentration [w/w\%] & 40 & 40 & 40 \\
$\mathrm{CO}_{2}$ lean loading \\
$\begin{array}{l}\text { mole } \mathrm{CO}_{2} / \text { mole MEA ] } \\
\text { Solvent flow rate [kg/s] }\end{array}$ & 0.27 & 0.27 & 0.25 \\
& 2212 & 2422 & 2483 \\
\hline
\end{tabular}

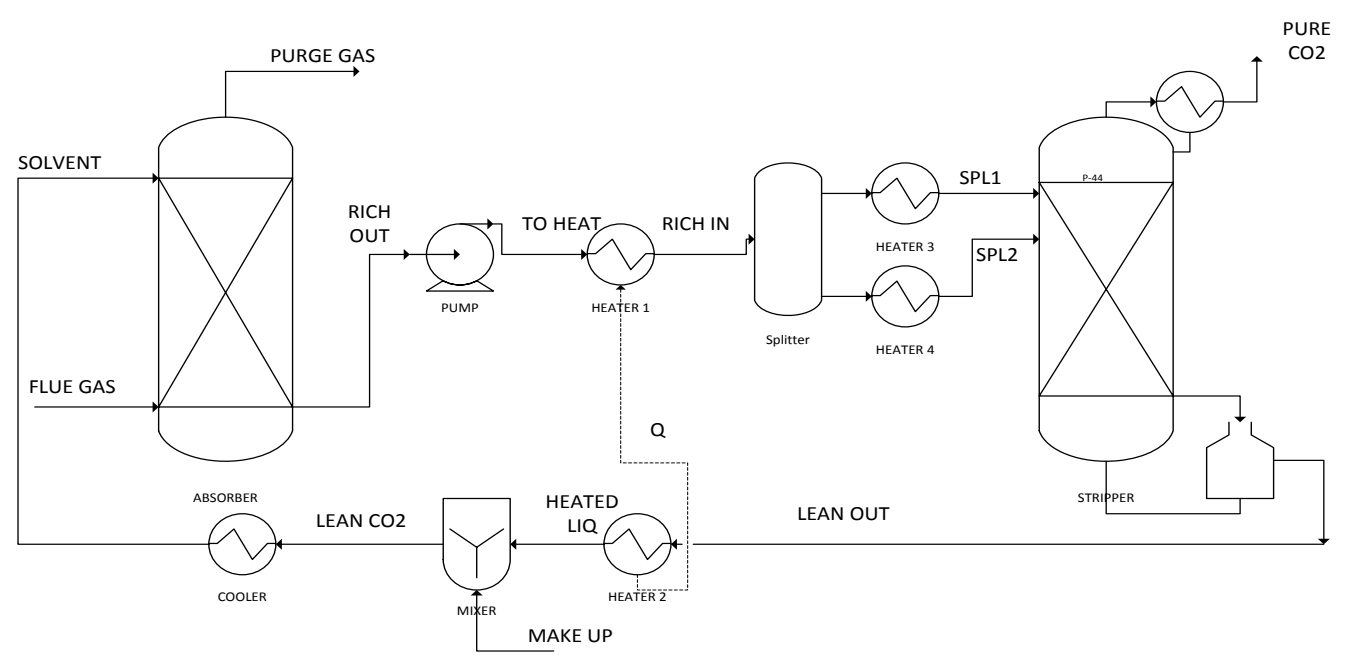

Fig. 2. Process flow diagram after modifications

\section{A. Reactions and Equilibrium Data}

The equations (1) - (7) show the basic reactions between $\mathrm{CO}_{2}$ and amine solvent [7].

$$
\begin{aligned}
& 2 \mathrm{H}_{2} \mathrm{O} \leftrightarrow \mathrm{OH}^{-}+\mathrm{H}_{3} \mathrm{O}^{+} \\
& \mathrm{H}_{2} \mathrm{O}+\mathrm{H}_{2} \mathrm{~S} \leftrightarrow \mathrm{HS}^{-}+\mathrm{H}_{3} \mathrm{O}^{+} \\
& \mathrm{H}_{2} \mathrm{O}+\mathrm{HS}^{-} \leftrightarrow \mathrm{S}^{2-}+\mathrm{H}_{3} \mathrm{O}^{+} \\
& \mathrm{CO}_{2}+2 \mathrm{H}_{2} \mathrm{O} \leftrightarrow \mathrm{HCO}_{3}^{-}+\mathrm{H}_{3} \mathrm{O}^{+} \\
& \mathrm{HCO}_{3}^{-}+\mathrm{H}_{2} \mathrm{O} \leftrightarrow \mathrm{H}_{3} \mathrm{O}^{+}+\mathrm{CO}_{3}^{2-} \\
& \mathrm{MEAH}^{+}+\mathrm{H}_{2} \mathrm{O} \leftrightarrow \mathrm{MEA}+\mathrm{H}_{3} \mathrm{O}^{+} \\
& \mathrm{MEACOO}^{-}+\mathrm{H}_{2} \mathrm{O} \leftrightarrow \mathrm{MEA}+\mathrm{HCO}_{3}^{-}
\end{aligned}
$$

The kinetic behavior of the process is given in the following section. The equations (8) to (11) represent the kinetic behavior of the process.

$$
\mathrm{CO}_{2}+\mathrm{OH}^{-} \leftrightarrow \mathrm{HCO}_{3}^{-}
$$

$$
\mathrm{MEA}+\mathrm{CO}_{2}+\mathrm{H}_{2} \mathrm{O} \leftrightarrow \mathrm{MEACOO}^{-}+\mathrm{H}_{3} \mathrm{O}^{+}
$$

$$
\mathrm{HCO}_{3}^{-} \leftrightarrow \mathrm{CO}_{2}+\mathrm{OH}^{-}
$$

$$
\mathrm{MEACOO}^{-}+\mathrm{H}_{3} \mathrm{O}^{+} \leftrightarrow \mathrm{MEA}+\mathrm{CO}_{2}+\mathrm{H}_{2} \mathrm{O}
$$

The thermodynamic and kinetic data are selected according to the literatures [8].

\section{B. Details of New Process Configuration}

The purpose of designing a new process model is to optimize the carbon capture process with low re-boiler duty. Different split ratio and inlet temperature of split streams are varied to select the optimum values. The split ratio 0.6 is selected as the base case value for this simulation. The inlet temperatures of split streams are selected as $118^{\circ} \mathrm{C}$ for stripper section in the simulation model. The process model is developed for $85 \%, 90 \%$ and $95 \%$ removal efficiencies. The efficiency of the $\mathrm{CO}_{2}$ removal $(85 \%, 90 \%$, and $95 \%)$ is achieved with distillate rate (vapor stream of the stripper outlet) variation in the stripper. The required solvent condition for carbon capture model is selected from previous simulation studies [6]. The stage of the inlet streams to the stripper is selected to get the lowest re-boiler duty. The stage number 2 and 6 are selected for the new process. The required re-boiler duty for new process is calculated and compared with the conventional process. The re-boiler dury for new process configuration is calculated as combination of the stripper re-boiler energy and the energy of the new heaters (heater 3 and 4). Temperature and concentration profiles are analyzed for both processes. The base case 
process after changing the process model configuration (Fig. 2 ) is used for sensitivity analyses. The split ratio in the splitter column, temperatures of the split streams (SPL 1 and 2) as well as the stage number of the stripper column is varied to check the effect on the re-boiler energy requirement in striper.

\section{RESULTS}

Due to similar parameter conditions in absorber unit, temperature and concentration profiles remain unchanged [9]. The effect of splitter ratio on re-boiler duty (heater 3 and 4 energy plus re-boiler energy in stripper) is negligible. However, heater 3 and 4 heat duties are varied according to the splitter ratio, but total amount of heat required is constant. Fig. 3 and 4 show the split ratio effect on re-boiler duty and heat duties of heater 3 and 4 .

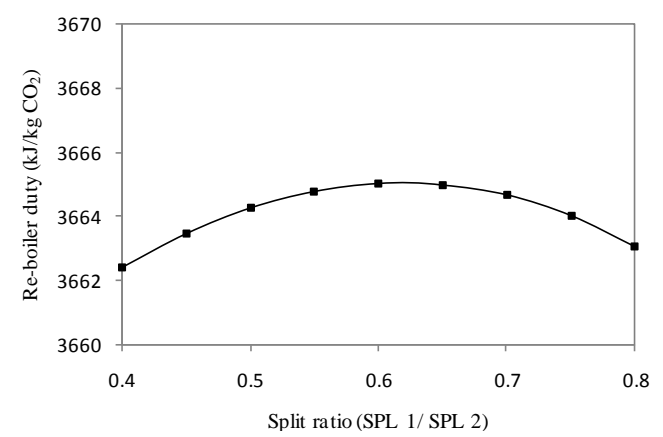

Fig. 3. Split ratio effect on re-boiler duty

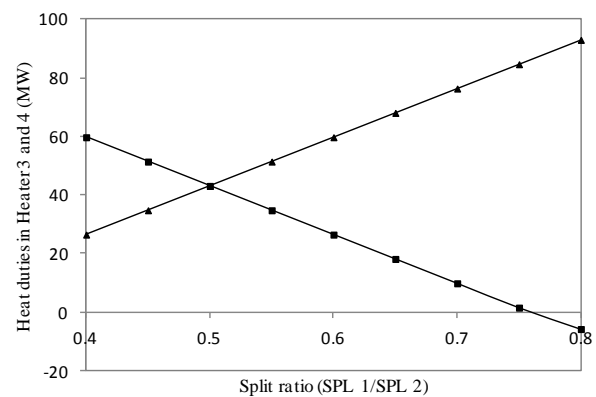

Fig. 4. Variation of heat duties in heater $3(\boldsymbol{\Delta})$ and heater $4(\boldsymbol{\square})$ with split ratio

As can be seen from the Fig. 3, the effect of the split ratio on re-boiler duty is negligible. Even though, heater 3 and 4 duties are changing with the split ratio, combination of duty of heater 3 and 4 are remain constant.

The effect of heater 3 and 4 temperature (temperature of SPL 1 and SPL 2) on re-boiler duty (Fig. 5) and heat duties of heaters (Fig. 6) are studied. The temperatures of SPL 1 and SPL 2 are varied from $110^{\circ} \mathrm{C}$ to $120^{\circ} \mathrm{C}$. When the effect of SPL 1 is varied, SPL 2 temperature is maintained at $118^{\circ} \mathrm{C}$ as similar to base case value.

It can be seen from Fig. 5, re-boiler duty and heat duty of heater 3 are increasing with the increase of SPL 1 temperature.

Similar to that, variation of re-boiler duty and heat duties of heater 3 and 4 are studies by changing the SPL 2 temperature as given in Fig. 7 and Fig. 8 respectively.

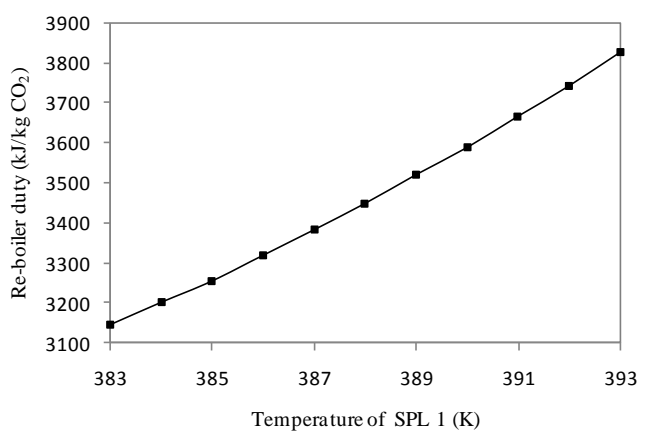

Fig. 5. SPL 1 temperature effect on re-boiler duty

The effects of the feed stream position (stage number) on the re-boiler energy demand and heat duties of the heaters are negligible.

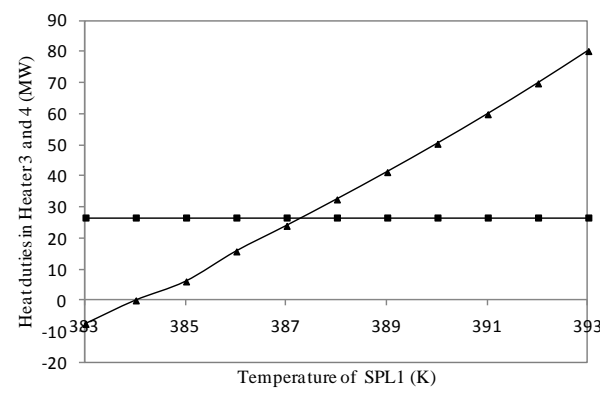

Fig. 6. Variation of Heat duties in heater $3(\boldsymbol{\Delta})$ and heater $4(\mathbf{\square})$ with SPL 1 temperature

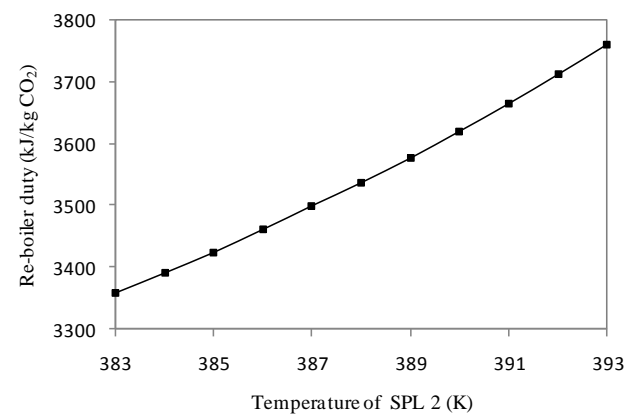

Fig. 7. SPL 2 temperature effect on re-boiler duty

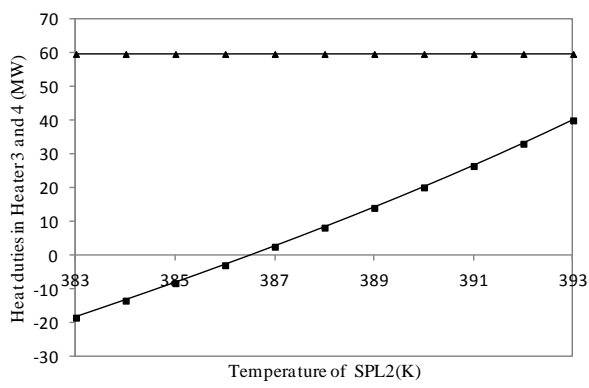

Fig. 8. Variation of Heat duties in heater $3(\boldsymbol{\Delta})$ and heater $4(\boldsymbol{\square})$ with SPL 2 temperature

According to the simulation results, optimum operating conditions for new configuration is selected. Temperatures of SPL 1 and 2 are selected as $111^{\circ} \mathrm{C}$ and $114^{\circ} \mathrm{C}$ as those values are given almost zero heat duty for heater 3 and 4 . Using optimum operating conditions, simulations were performed to check the required energy demand for re-boiler. Re-boiler energy demand calculated as $3255 \mathrm{~kJ} / \mathrm{kg} \mathrm{CO} \mathrm{CO}_{2}$ for $85 \%$ removal process. 


\section{Discussion}

The re-boiler duty requirement for the new process configuration vs. conventional model is given in the Table III. According to the comparison studies, re-boiler duty requirement has drastically decreased in new model configuration. As an example, re-boiler energy requirement for $85 \%$ removal process is $3255 \mathrm{~kJ} / \mathrm{kg} \mathrm{CO}_{2}$ in new model. This value is much lower compared to the conventional model value $3634 \mathrm{~kJ} / \mathrm{kg} \mathrm{CO}$ [9]. The reason behind this observation is inlet stripper temperature is high in new process and only part of the water vapor and $\mathrm{CO}_{2}$ rich solvent enter to the middle of the column to re-generate. Due to splitter, part of the $\mathrm{CO}_{2}$ already separated and enter to the stripper as $\mathrm{CO}_{2}$ itself and leave the column at the top without contacting with steam to re-generate the solvent. Therefore, required steam for re-generation section is decreased compared to the conventional process. Another reason for reduction of re-boiler duty is temperatures of stripper inlet streams are high. Therefore, energy required increases the temperature in stripper for re-generation process and water evaporation is low. The main target of the process modification was to reduce the re-boiler energy requirement. However, capital cost of the process is increasing due to new unit operation blocks added to the new model. The splitter unit and two heat exchangers are newly added to the process optimization. There may be some discussion for new heat exchangers. There are some heat taken by the newly added heaters (Heater 3 and 4). However, that amount is comparatively low. Even though, there is another heat exchanger unit before the splitter section, it is not practical to increase the outlet temperature of that heat exchanger due to heat transferring problems. It is compulsory to keep temperature different between inlet and outlet of stream line enter to the heat exchanger system for better heat exchanging. Therefore, the inlet of the splitter temperature is maintained at optimum value $110^{\circ} \mathrm{C}$ for better heat exchanging. The temperature of the split stream are maintained using two newly added heat exchangers. The economic evaluation of the process has to be performed to understand the feasibility of installing new process configuration. The trade-off between capital cost and operating cost including energy requirement in re-boiler duty will decide the advantage of the new process configuration.

TABLE III. COMPARISON OF RE-BOILER DUTY REQUIREMENT

\begin{tabular}{lccc}
\hline $\begin{array}{c}\text { Re-boiler duty } \\
\left(\mathrm{kJ} / \mathrm{kg} \mathrm{CO}_{2}\right)\end{array}$ & $\begin{array}{c}85 \% \\
\text { Removal } \\
\text { Efficiency }\end{array}$ & $\begin{array}{c}90 \% \\
\text { Removal } \\
\text { Efficiency }\end{array}$ & $\begin{array}{c}95 \% \\
\text { Removal } \\
\text { Efficiency }\end{array}$ \\
\hline $\begin{array}{l}\text { Conventional } \\
\text { model(Fig. 1) }\end{array}$ & 3634 & 3736 & 4185 \\
New model (Fig. 2) & 3255 & 3360 & 3614 \\
\hline
\end{tabular}

\section{CONCLUSION}

This paper discuss about possible model configurations to improve the carbon capture process with reduction of re-boiler duty. The new model is developed to achieve the target. Rich solvent stream before entering to the stripper section is split using splitter unit operation block and heated up to $111^{\circ} \mathrm{C}$ and $114^{\circ} \mathrm{C}$. The split ratio is selected as 0.6 for better performance. The two split streams are added in stage number 2 and 6 in stripper column. The re-boiler duty of $85 \%, 90 \%$ and $95 \%$ efficiency removal are calculated for new process configuration and it is 3255 , 3360 and $3614 \mathrm{~kJ} / \mathrm{kg} \mathrm{CO}$, respectively. The re-boiler energy requirement is drastically decreased for new process configuration. The trade-off between capital cost and energy cost for operating capture plant will decide the feasibility of the process.

\section{REFERENCES}

[1] S. Anderson and R. Newell, "Prospects for carbon capture and storage technologies," discussion paper, Resources for the future, January 2003.

[2] D. Jeremy and H. J. Herzog, "The cost of carbon capture," in Proc. of the 5th International Conference on green house gas control technologies, Cairns, Australia, 13-16 August 2000.

[3] C. F. Alie, " $\mathrm{CO}_{2}$ Capture with MEA: Integrating the Absorption Process and Steam Cycle of an Existing Coal-Fired Power Plant," Master Thesis, University of Waterloo, Canada, 2004.

[4] Aspen Plus, "Aspen Physical Property Methods," Aspen Technology Inc., Cambridge, MA, USA, pp. 61-63, 2006.

[5] U. S. P. R. Arachchige and M. C. Melaaen, "Selection of Packing Material for Gas Absorption," European Journal of Scientific Research, vol. 87, no. 1, pp. 117-126, 2012.

[6] U. S. P. R. Arachchige, M. Muhammad, and M. C. Melaaen, "Optimization of post combustion carbon capture process-solvent selection," International Journal of Energy and Environment, vol. 3, no. 6, pp. 861-870, 2012

[7] A. D. Michael, "A model of vapour-liquid equilibria for acid gas-alkanolamine-water systems," Ph.D. Thesis, University of Texas, USA, 1989.

[8] S. Freguia, "Modeling of $\mathrm{CO}_{2}$ removal from Flue Gas with Mono-ethanolamine," Master Thesis, University of Texas, Austin, USA, 2002.

[9] U. S. P. R. Arachchige, M. Muhammad, and M. C. Melaaen, "Optimized CO2-flue gas separation model for a coal fired power plant," Submitted to International Journal of Energy and Environment, 2013.

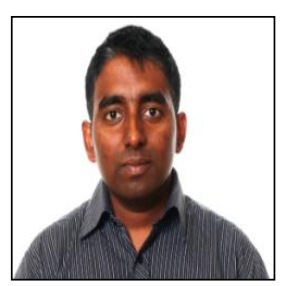

Udara S. P. R. Arachchige received his B.Sc. Degree (2007) in Chemical and Process Engineering from University of Moratuwa, Sri Lanka and M.Sc degree (2010) in Energy and Environmental Engineering from Telemark University College, Porsgrunn, Norway. He is presently pursuing his Ph.D. in Carbon dioxide capture from power plantsmodeling and simulation studies at Telemark University College. He has presented and published nine papers in International Conferences. Mr. Udara is a member of American Chemical Society.

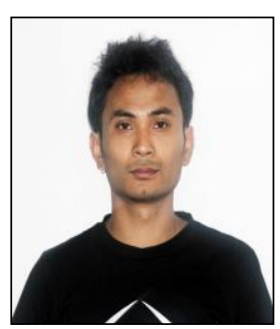

Dinesh Kawan received his B.E Degree (2010) in Electronics and Communication Engineering from Khwopa Engineering College, Purbanchal University, Nepal. He is presently pursuing his Master degree in System and Control Engineering in Telemark University College, Porsgrunn, Norway. $\mathrm{He}$ also working as a research assistant at faculty of Technology in same university college. Mr. Kawan has research interest on carbon capture, modeling and simulation, and control systems in process industries. 


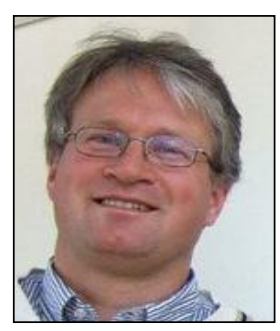

Morten Chr. Melaaen is Professor in process technology at Telemark University College, Porsgrunn, Norway. He is also the Dean of Faculty of Technology, Telemark University College and has a part time position at the local research institute TelTek. Earlier, he has worked as a research engineer in Division of Applied Thermodynamics, SINTEF, Norway and as an Associate professor at Norwegian University of Science and Technology (NTNU).

He has worked on research projects as a Senior research scientist in Norsk Hydro Research Centre Porsgrunn, Norway. He started to work as a professor at Telemark University College in 1994 and became Head of Department, Department of Process, Energy and Environmental Technology in 2002. He received his MSc in Mechanical Engineering in 1986 and his Ph.D. in 1990, both from NTNU. His research interests are $\mathrm{CO}_{2}$ capture, modeling and simulation, fluid mechanics and heat and mass transfer. Professor Melaaen has more than 95 scientific papers published in the above mentioned related fields in international journals and conferences. 